\title{
POTENSI SEL T MOBIL HER2 SPESIFIK MODIFIKASI CRISPR / CAS9 PD-1 / PD-L1 PEMBLOKIRAN SEBAGAI INOVASI TERAPI UVEAL MELANOMA
}

\author{
Mukhammad Arif Hadi Khoiruddin ${ }^{1}$, Yusi Windya Febriyanti², Nafia Amalia ${ }^{3}$ \\ 1,2,3 Program Studi Pendidikan Dokter, Fakultas Kedokteran, Universitas Jember \\ 1e-mail : arifhakz08@gmail.com
}

\begin{abstract}
Uveal Melanoma (UM) is the primary intraocular tumor most commonly found in adults. The combination of therapy, Brachytherapy, surgery, Tranpupillary Thermal Therapy (TTT), Proton Beam Theraphy has not produced satisfactory results. The discovery of HER2 receptors expressed by UM cells can be used as a specific antigen target for the treatment of CAR T-celss. However, the effectiveness of CAR T-cell immunotherapy in tumors results in immunosuppressive T cells caused by an increase in Programmed cell Death Ligand-1 (PDL1). This literature review demonstrates the success of HER2-specific CART T Cells as UM therapeutic efforts capable of eliminating tumor cells. In addition, CRSPR / Cas 9 PD-1 / PD-L1-blocking modified HER2-specific CAR $T$ cells can be a gene innovation in UM sufferers. Further clinical trials are needed to prove the effectiveness of CRISPR / Cas9 PD-1 / PD-L1-Blocking modified HER2-specific CAR T Cells in the treatment of UM patients.
\end{abstract}

Keywords:

Uveal melanoma, CAR T cell, reseptor HER

\begin{abstract}
Abstrak
Uveal Melanoma ( UM ) adalah tumor intraocular primer yang paling sering ditemukan pada orang dewasa. Kombinasi terapi, Brachiterapi, pembedahan, Tranpupillary Thermal Therapy (TTT), Proton Beam Theraphy belum menghasilkan hasil yang memuaskan. Penemuan reseptor HER2 yang diekspresikan oleh sel UM dapat digunakan sebagai target antigen spesifik untuk terapi CAR T-celss. Akan tetapi, efektivitas imunoterapi CAR Tcells pada tumor menimbulkan imunosupresif sel T yang diakibatkan oleh peningkatan Programmed cell Death Ligand-1 ( PD-L1). Tinjauan literature ini menunjukkan keberhasilan CART T Cells HER2-specific sebagai upaya terapi UM yang mampu melakukan eliminasi sel tumor. Selain itu, HER2-specific CAR T cells termodifikasi CRISPR/Cas9 PD-1/PD-L1-blocking dapat menjadi inovasi gen pada penderita UM. Diperlukan uji klinis lebih lanjut untuk membuktikan efektivitas CAR T Cells HER2-specific termodifikasi CRISPR/Cas9 PD-1/PD-L1-Blocking dalam rangka terapi pasien UM.
\end{abstract}

Kata kunci : Uveal melanoma, CAR T cell, reseptor HER

\section{PENDAHULUAN}

Uveal Melanoma ( UM ) adalah tumor intraokular primer yang paling sering ditemukan pada orang dewasa ${ }^{1-3}$. UM paling sering muncul dari melanosit koroid $(85 \%-90 \%)$, tetapi juga dapat timbul dari iris $(3 \%-5 \%)$ dan ciliary body $(5 \%-8 \%)^{1,4,5}$. UM sering terdiagnosis pada pasien usia antara 55-60 tahun. Insidensi UM adalah 5 dari 1.000 .000 dan setiap tahunnya terdiagnosis 1.500 kasus baru di amerika dan eropa ${ }^{3,6,7}$. Meskipun pasien UM biasanya memiliki gejala seperti penglihatan kabur, visual field defect, metamorphopsia, atau photopsia, $30 \%$ pasien UM bersifat asimptomatik dan terdeteksi secara tidak sengaja setelah pemeriksaan mata rutin ${ }^{8}$. Pasien dengan UM memiliki prognosis yang buruk karena uveal melanoma memiliki kecenderungan yang tinggi untuk bermetastasis pada organ organ lain seperti hepar $(89 \%)$, paru-paru $(29 \%)$, tulang $(17 \%)$, kulit dan jaringan subcutan $(12 \%)$, serta kelenjar (11\%) sehingga meningkatkan angka mortalitas pasien ${ }^{9}$. Selain itu beban biaya yang ditimbulkan 
sebesar $\$ 106.100$ atau hampir $1,503,769,000 \cdot 00^{10-11}$. Akan tetapi dengan pembiayaan yang cukup besar tersebut tidak bisa menjamin kesembuhan pasien sepenuhnya ${ }^{12}$.

Modalitas terapi seperti Brachiterapi, pembedahan, Tranpupillary Thermal Therapy (TTT), Proton Beam Theraphy tetap menunjukkan hasil kurang memuaskan. brachiterapi banyak menimbulkan banyak efek samping ${ }^{1,5.13}$. Resiko komplikasi sebesar 25,3\% dan $50,3 \%$ akan menimbulkan beberapa efek samping lain diantaranya retinopati ( $16,8 \%$ ), mokolupati ( $38,5 \%)$, optik neuropati ismkemik $(25,2 \%)$, retinal detachment $(18,9 \%)$, vitreous hemorrhage ( $17,5 \%$ ), tumor vaskulopati $(21 \%)$. Selain itu terapi pembedahan juga menimbulkan beberapa efek samping diantaranya retinal detachment ( $21 \%$ ), hipertensi okular ( $21 \%)$, submacular hemorrhage $(16 \%)$ dan repeat vitreoretinal surgery $(44-70 \%)^{11}$. TTT ( Transpupillary thermal therapy ) juga menimbulkan efek samping irish atrofi $36 \%$, peripheral focal lens opacity $24 \%$, obstruksi vascular $2 \%$. Proton Beam Therapy juga menimbulkan efek samping diantaranya gangguan pendengaran ( $25 \%$ ), penurunan kognitif sebesar 1,9/tahun ${ }^{14}$.

Seiring dengan kemajuan teknologi berbasis imunoterapi, penemuan metode CAR T-Cells telah membukakan jalan menuju era baru terapi kanker dengan hasil yang meyakinkan dan memberikan harapan besar $^{15}$. Selain itu, penemuan reseptor HER2 yang diekspresikan oleh sel tumor UM bisa digunakan sebagai target antigen spesifik untuk terapi CAR T-cells dalam UM sehingga mampu menjadi suatu inovasi pengobatan terbaru untuk $\mathrm{UM}^{16}$. Akan tetapi salah satu tantangan utama untuk efektivitas imunoterapi CAR Tcells pada tumor berupa keadaan imunosupresif sel $\mathrm{T}$ yang diinduksi oleh sel tumor yang diakibatkan oleh peningkatan Programmed cell Death Ligand-1 (PD-L1) ${ }^{17}$. Ikatan antara PD- L1 dengan Programmed cell Death-1 (PD-1) akan menghambat aktivasi, proliferasi, dan kelangsungan hidup sel $\mathrm{T}^{17,18}$. Salah satu strategi untuk menurunkan ekspresi PD-1 adalah dengan melakukan rekayasa genetika menggunakan CRISPR/Cas9 yang mampu mendelesi gen pded-1 sehingga dapat menghambat ikatan antara PD-1 dan PD-L1. Akibatnya. terjadi peningkatan efek antitumor CAR T- Cells pada terapi $\mathrm{UM}^{19}$.

\section{METODE}

Penulisan tinjauan pustaka ini mengguanakan metode Prefferd Reprting Items for Systemic Reviews and Meta Analyses (PRISMA). PRISMA adalah suatu tinjauan pustaka yang didasarkan atas fakta-fakta dan pengambilan studi pustaka secara acak. Penulis menggunakan search engine berupa Pubmed, Science Direct, Google Schoolar, Nature dengan kata kunci: "Uveal Melanoma, CAR T Cells, HER2, CRISPR/Cas9, PD-1/PDL1". Judul dan abstrak akan menjalani proses pemindaian untuk mengeksklusi jurnal ilmiah yang bersifat tidak relevan dengan kata kunci. Dalam tinjauan pustaka ini, kami menggunakan jurnal ilmiah yang membahas tentang mekanisme dan aspek klinis dari CAR T Cells dalam terapi Uveal Melanoma. Jurnal ilmiah akan menjalani proses eksklusi jika tahun penerbitan melebihi 10 tahun. Terdapat 77 jurnal ilmiah yang sesuai dengan topik yang dibahas, namun hanya 46 jurnal yang memenuhi kriteria inklusi yang telah ditetapkan.

\section{HASIL DAN PEMBAHASAN}

\section{CAR T Cells menarget reseptor spesific}

The human epidermal growth factor receptor (HER) berperan sentral dalam patogenesis beberapa kanker pada manusia $^{20}$. HER mengatur pertumbuhan sel, kelangsungan hidup, dan diferensiasi melalui jalur transduksi sinyal ganda dan dalam proliferasi serta diferensiasi seluler. HER terdiri dari empat macam yaitu: HER-1, HER-2, HER-3, dan HER-4, juga 
disebut ErbB1, ErbB2, ErbB3, dan ErbB4 ${ }^{21}$. Banyak peneliti menunjukkan adanya ekspresi HER2 selama perkembangan uveal melanoma dan metastasis berbeda dengan melanosit normal. Peningkatan ekspresi HER2 muncul pada 8 dari 10 pasien dengan melanoma metastasis ${ }^{16}$.

\section{Chimeric Antigen Receptor T Cells (CAR T Cells)}

Selama beberapa dekade, terapi kanker hanya mengandalkan operasi, kemoterapi, dan radioterapi. Dalam beberapa tahun terakhir, konsep imunoterapi dikembangkan sebagai alternatif pengobatan baru berbagai jenis kanker. Salah satu metode yang menjanjikan adalah transfer sel $\mathrm{T}$ yang direkayasa secara genetika dengan mengekspresikan Chimeric Antigen Receptor (CAR), yang kemudian disebut sebagai CAR T Cells (Gambar 1A ${ }^{22}$. CAR T Cells tersebut mampu mengenali antigen spesifik pada permukaan sel tumor. Metode CAR $\mathrm{T}$ Cells memanfaatkan sel $\mathrm{T}$ yang diisolasi dari darah pasien atau donor, kemudian diaktifkan dan direkayasa secara genetika untuk mengekspresikan reseptor CAR. Setelah itu, sel $\mathrm{T}$ yang telah direkayasa akan dikembangkan jumlahnya secara ex vivo dan tahap akhir menjadi produk berupa infus ${ }^{22}$. CAR sendiri merupakan reseptor sintetis yang diekspresikan oleh sel T. Reseptor CAR dalam sel $\mathrm{T}$ terdiri dari single-chain variable fragment ( $\mathrm{scFv}$ ), domain transmembran, dan bagian intraseluler berupa immunoreceptor tyrosine-based activation motifs (ITAMs). Fragmen $\mathrm{scFv}$ sendiri bertindak sebagai tumor- associated antigens receptor (TAAs) atau reseptor antigen yang diekspresikan oleh sel-sel tumor ${ }^{23}$.

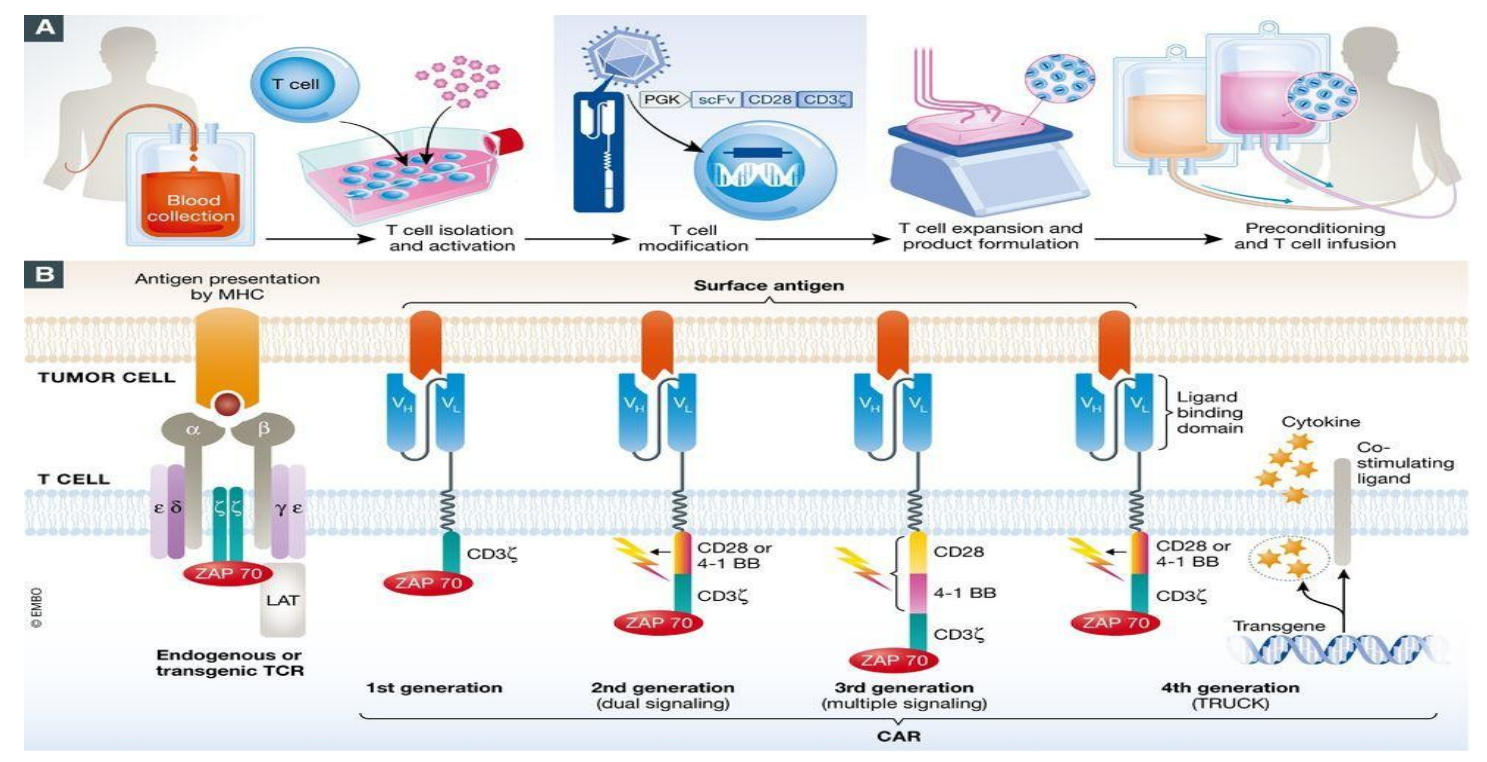

Gambar 1. A. Proses Rekayasa Genetik CAR T Cells, B. Struktur CAR T-cells ${ }^{22}$

CAR secara spesifik dapat berikatan dengan antigen spesifik permukaan sel kanker $^{22}$. Ikatan yang dibentuk antara reseptor CAR dan TAA ini akan menghasilkan sinyal transduser pada sel $\mathrm{T}$ melalui reseptor $\mathrm{CD} 3 \xi$ atau Fc. Proses pengiriman sinyal ini meningkatkan fungsi efektor sel $\mathrm{T}$ sebagai penghancur sel kanker $^{24}$.

CAR T Cells mampu mengenali secara spesifik antigen yang dipresentasikan oleh sel tumor. Ketika reseptor CAR secara spesifik mengikat TAA, sel $\mathrm{T}$ akan diaktifkan melalui fosforilasi ITAM sehingga sel $\mathrm{T}$ mengeluarkan sitokin yang akan terus berproliferasi dan menunjukkan efek sitotoksik pada sel tumor. Immunoreceptor chimeric secara aktif menunjukkan efek sitotoksik melalui 2 jalur, yaitu (1) sekresi granul perforin dan 
granzyme dan (2) aktivasi reseptor sinyal yang menginduksi kematian sel melalui Fas/Fas-ligand (Fas-L) atau TNF/TNF-R ${ }^{25}$. Tranduksi sinyal multireseptor pada CAR T-cells meningkatkan amplifikasi, produksi sitokin, dan efek sitotoksik pada sel T, dan mengurangi antigen-induced cell death (AICD) atau kematian sel yang diinduksi oleh antigen pada studi dan penelitian secara in vitro maupun in vivo ${ }^{26}$.
Sel $\mathrm{T}$ yang dimodifikasi ini meningkatkan proliferasi dan sekresi sitokin dari sel Th1, termasuk IL-2, IFN- $\gamma$, IL-12, dan $\mathrm{TNF}^{27}$. IL-12 yang diinduksi oleh CAR T-cells menginduksi aktivitas sel $\mathrm{T}$ sitotoksik ${ }^{28}$. Sitokin transgenik lain seperti IFN- $\gamma$ yang disekresikan oleh CAR T-cells berkontribusi sebagai antigen independen yang akan menghancurkan sel tumor ${ }^{29}$.

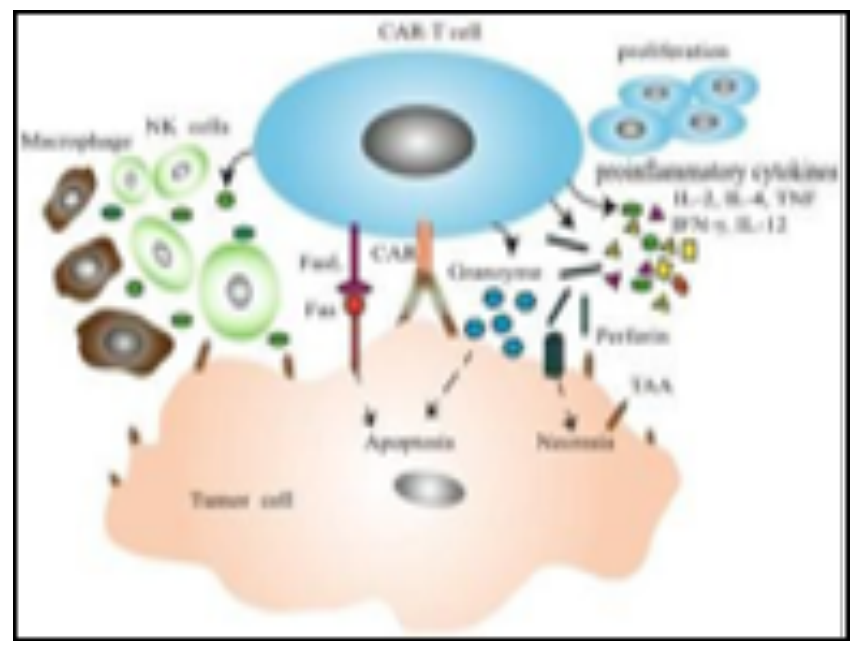

Gambar 2. Mekanisme Kerja CAR T Cells ${ }^{22}$

melalui mekanisme pensinyalan IFN- $\gamma \mathrm{R}$, reseptor IFN-on pada membran sel tumor Kemajuan terapi CAR $\mathrm{T}$ Cells terlihat dalam keberhasilannya mengatasi leukemia dan limfoma, sehingga semakin banyak penelitian yang berfokus pada pengujian terapi ini pada kasus tumor seperti $\mathrm{UM}^{30-32}$.

\section{Aplikasi HER2-CAR T Cells pada UM}

Sebuah penelitian yang dilakukan oleh Forsberg er al berhasil membuat desain konstruksi CAR T Cells HER2- Specific yaitu CAR $\mathrm{T}$ Cells dengan scFv yang disesuaikan terhadap target HER2 dalam luciferin sehingga mampu mengkode CD28 transmembrane, dan aktivasi CD3zeta. Percobaan ini dilakukan dengan dosis tunggal CAR T Cells sebesar $5 \times 10^{5}$ sel yang diberikan secara infus intravena ${ }^{16}$

\section{PD-1/PD-L1 Penyebab Imunosupresif}

Salah satu tantangan utama efektivitas imunoterapi CAR T-cells pada GBM berupa keadaan imunosupresif yang menekan kemampuan antitumor inang ${ }^{33,34}$. Sel tumor mampu menginduksi jalur regulasi endogen yang secara langsung menghambat fungsi efektor sel $\mathrm{T}$. Jalur regulasi endogen penghambat ini berupa aktivasi PD-133. PD-1 merupakan reseptor yang diekspresikan pada permukaan sel $\mathrm{T}$ dan memainkan peran penting dalam mengatur sistem kekebalan tubuh dengan menekan aktivitas sel $\mathrm{T}$ efektor. Pada manusia, PD-1 ditranskripsikan oleh gen pdcd1. Sebagai reseptor, PD-1 memiliki dua ligan yaitu PD-L1 (B7-H1) dan PD-L2 (B7-DC) yang ekspresikan di permukaan sel tumor. Ketika PD-1 berikatan dengan ligan-ligannya, ia akan menginduksi terjadinya apoptosis sel $\mathrm{T}$ efektor dan sel $\mathrm{T}$ regulatori (Treg) $)^{34}$ 


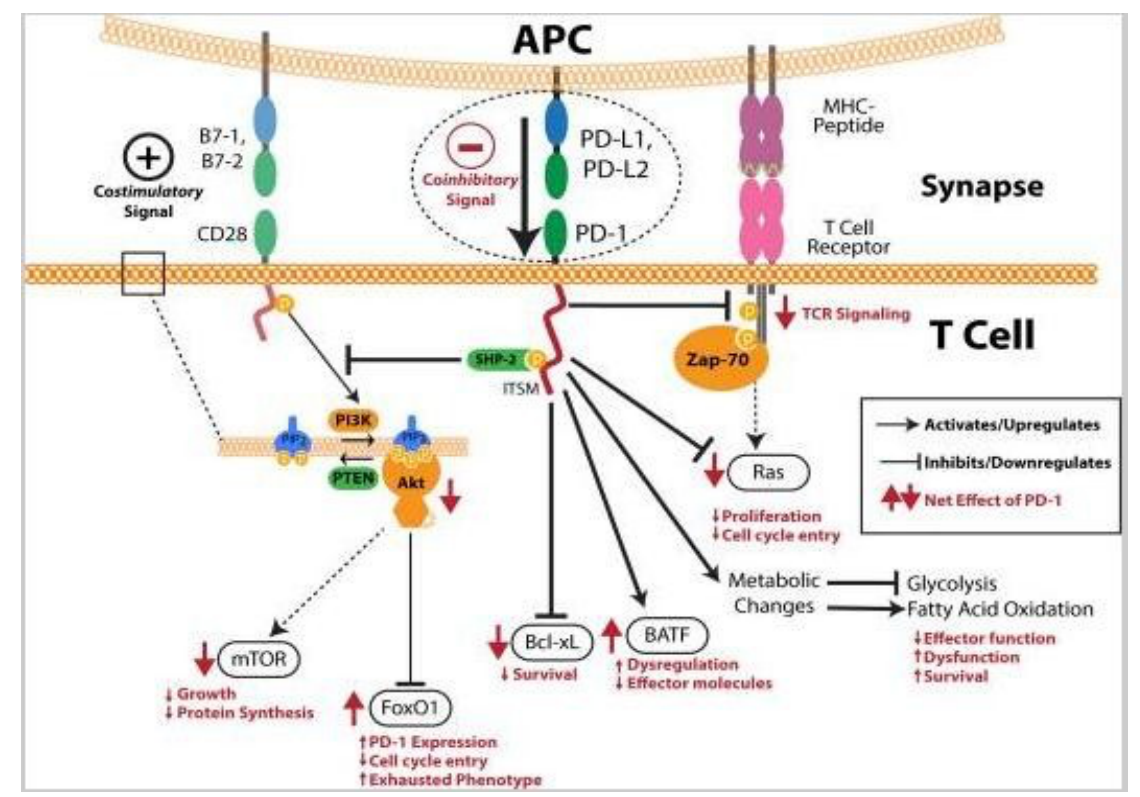

Gambar 3. Mekanisme Penekanan Efek Toksisitas Sel T oleh PD-1/PD-L1 ${ }^{37}$

Dalam microenvironment sel tumor, PD-1 dan PD-L1 melakukan peran vital dalam perkembangan dan kelangsungan hidup sel tumor $^{35}$. PD-1 memiliki komponen immunoreceptor tyrosinebased switch motif (ITSM) dalam intraselnya and immunoreceptor tyrosinebased inhibitory motif (ITIM) di ujung sitoplasmiknya. Ikatan antara PD-L1 dengan PD-1 menghasilkan fosforilasi tirosin pada sitoplasma PD-1 yang selanjutnya akan merekrut SHP-2 (SRC Homology 2 Domain Containing protein Tyrosine Phosphatase 2) yang letaknya dekat dengan reseptor sel T. Ikatan PD-1 PD-L1 menghambat aktivasi reseptor selsel kinase proksimal, yang menghasilkan depresi pada fosforilasi ZAP-70 dan dimediasi oleh Lck ${ }^{36}$. Pensinyalan PI3K/Akt adalah target penting dari jalur PD-1 seperti yang tertera pada gambar 5 . PD-1 menyebabkan downregulation Ras dan Bcl-xL yang mempengaruhi proliferasi dan kelangsungan hidup sel. Selain itu, peningkatan BATF juga dapat mengganggu fungsi efektor sel T. PD-1 juga berperan dalam menghambat jalur phosphat idylinositol 3-kinase (PI3K)/ Akt yang selanjutnya menghambat aktivasi PI3K. Pensinyalan PD-1 juga memengaruhi metabolisme seluler dengan menghambat glikolisis dan mendorong oksidasi asam lemak. Semua efek ini menyebabkan sel $\mathrm{T}$ tidak mampu berproliferasi, kehilangan fungsi efektornya, dan mengalami kelelahan hingga menjadi sel yang disfungsi ${ }^{37}$.

\section{Modifikasi CAR $T$ Cells dengan CRISPR/Cas9 untuk menargetkan PD- 1/PD-L1}

Seperti yang telah dijelaskan sebelumnya, ikatan PD-1 dan PD-L1 dapat menginduksi apoptosis sel $\mathrm{T}$ dan dapat menekan efek imunitas. Secara fisiologi, beberapa jaringan manusia yang normal dapat mengekspresikan PD-L1 dalam jumlah kecil. Sebaliknya, pada saat terjadi tumor atau keganasan protein PD-L1 diekspresikan secara berlebih pada permukaan sel tumornya, seperti yang ditunjukkan pada imunohistokimia UM. Proses ikatan PD-1 dan PD-L1 pada sel tumor dapat menjadi penanda prognosis yang buruk dalam terapi. Untuk itu, diperlukan modifikasi rekayasa genetika untuk menekan ekspresi gen pdcd-1 dengan tujuan supaya tidak terbentuk ikatan PD-1/PD-L1. 
CRISPR/Cas9 saat ini merupakan metode rekayasa genetika termutakhir. Rekayasa genetika CRISPR/Cas9 mampu diterapkan pada sel T. Penelitian yang dilakukan oleh Rupp et. al menunjukkan silencing gen penghasil PD-1 (pdcd1) pada CAR $T$ Cells melalui metode CRISPR/Cas9 mampu meningkatkan efek anti-tumor $^{38}$. Dalam hal ini metode CRISPR/Cas9 PD-1/PD- L1-Blocking ditargetkan untuk mengganggu produksi PD-1 dalam sel T manusia.

Gen pded-1 yang akan menjadi target terletak di kromosom 2q37 dan mengandung 6 ekson $^{39}$. Proses rekayasa gen pdcd1 dengan CRISPR/Cas9 dimulai dengan melakukan pengambilan darah dari pasien atau donor. Selanjutnya dilakukan isolasi sel $\mathrm{T}$ limfosit dari darah tersebut. Setelah 7-10 hari akan didapatkan kloning sel $T$. Sel $T$ yang didapat ini kemudian dimodifikasi dengan CAR untuk menjadi CAR T Cells, selanjutnya dilakukan modifikasi menggunakan CRISPR/Cas $9^{40}$

Dalam metode CRISPR/Cas9, terdiri dari beberapa komponen yang berperan penting, yaitu guideRNA (gRNA), dan endonuklease cas $9^{39}$. Penargetan sekuens DNA pada sel manusia akan dipandu oleh sekuens pendek RNA yang selanjutnya akan dilakukan pemotongan oleh DNA endonuklease melalui Double Strand Breaks (DSBs) dengan efisiensi dan spesifitas yang tinggi ${ }^{38}$. Komponen Cas9 sendiri berfungsi untuk mengenali sekuens spesifik pada double strand. DNA melalui pengenalan oleh gRNA pada sekuens target di DNA sel. Cas9 memiliki 2 domain utama yaitu $\mathrm{HNH}$ yang berfungsi untuk memotong rantai DNA yang menjadi komplemen dari sekuens gRNA dan RuvC yang bertanggung jawab dalam pemotongan rantai DNA nontarget ${ }^{38,39}$.

Masing-masing komponen CRISPR/ Cas9 akan di masukkan ke dalam vektor agar memudahkan proses transfeksi, dalam hal ini vektor yang digunakan berupa lentivirus. Selanjutnya gRNA akan mengkodekan target gen pdcd-1 dan masuk ke dalam DNA sel T melalui proses endositosis. Di dalam nukleus, gen pdcd-1 yang dibawa oleh gRNA akan berikatan dengan komplemen gennya. Setelah proses ikatan terjadi, gRNA memicu pemotongan DNA akibat aktivitas protein Cas9 endonuklease ${ }^{41}$. Cas9 endonuklease akan melakukan pemotongan pada basa nukeotida 5'CGACTGGCCAGGGCGCCTGT-3 dan akan segera menghasilkan DSBs. DSBs yang dihasilkan akan diperbaiki oleh mekanisme endogen seluler seperti errorprone nonhomologous end joining(NHEJ) ${ }^{42,43}$. NHEJ dapat memicu terjadinya insersi atau delesi dan frameshift mutation kecil dan sembarang pada DNA yang terpotong ${ }^{44}$. Mutasi ini bersifat heterogenik dan tidak akan menimbulkan abnormalitas yang berarti pada DNA sel inang ${ }^{45}$ 


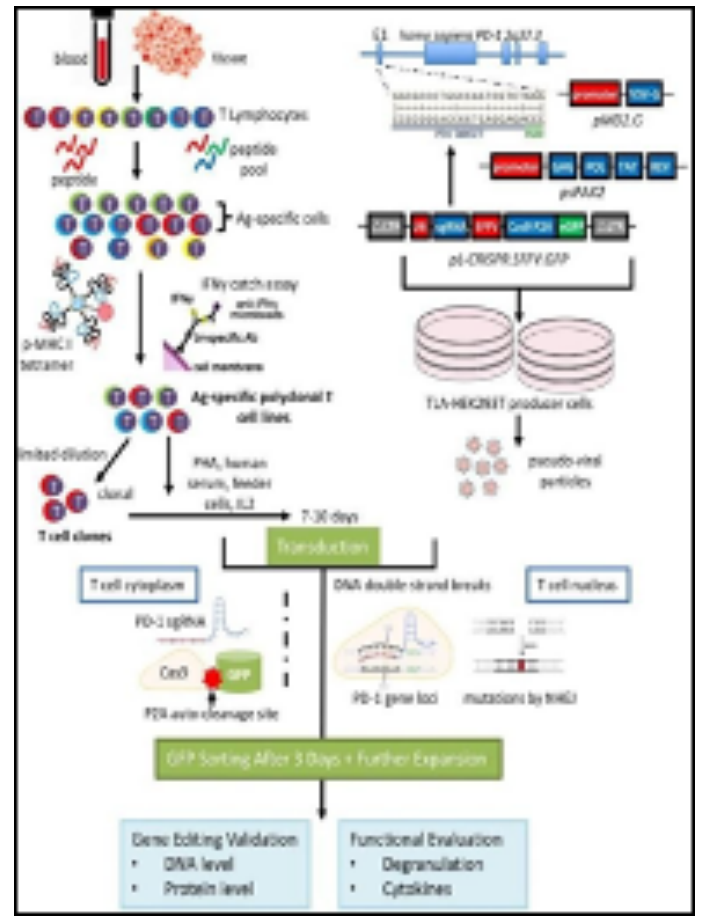

Gambar 4. Mekanisme Penekanan Efek Toksisitas Sel T oleh PD-1/PD-L1 ${ }^{45}$

\section{Peningkatan Potensi Antitumor pada CAR T Cells Termodifikasi}

Salah satu peneltian yang dilakukan oleh Rupp et al berhasil melakukan pengujian efek peningkatan potensi antitumor CAR $\mathrm{T}$ Cells yang telah dimodifikasi menggunakan CRISPR/Cas9. Untuk menentukan efek dari defisiensi PD-1 pada fungsi sel T, Rupp et al menguji pada CAR T Cells Anti-D19 dengan reseptor rekayasa invitro gangguan tersebut dapat menyebabkan degradasi pdcd1 yang ditunjukkan dengan menurunnya pengekspresian PD-1 dibandingkan dengan menurunnya pengekspresian PD-1 dibandingkan dengan kelompok control ${ }^{46}$.

Selain itu pada pengjian secara in vivo efek silencing gen pdcd 1 pada CAR $\mathrm{T}$
Cells dilakukan pada tikus yang diinjeksi secara subkutan. Hasil penelitian secara in vivo ini menunjukkan CRISPR/Cas9 yang menargetkan lokus pdcd1 efisien dalam proses silencing gen pded 1 dalam mengekspresikan PD-1. Hal ini menunjukkan bahwa terjadi peningkatan efektivitas anti-tumor pada percobaan. Hasil tersbut membuat Forsberg et al melakukan penelitian sejenis dengan target HER2 yang berada pada UM. Forsberg et al mendapat hasil serupa dimana terjadi penurunan yang signifikan terhadap kelompok kontrol seperti yang ditunjukkanpada gambar $5^{16}$. Hasil ini tentunya menjadi dasar teori baru tentang potensi CAR T Cells yang dimodifikasi dengan CRISPR/Cas9 dalam meningkatkan kemampuan anti- tumor sebagai upaya eradikasi UM. 


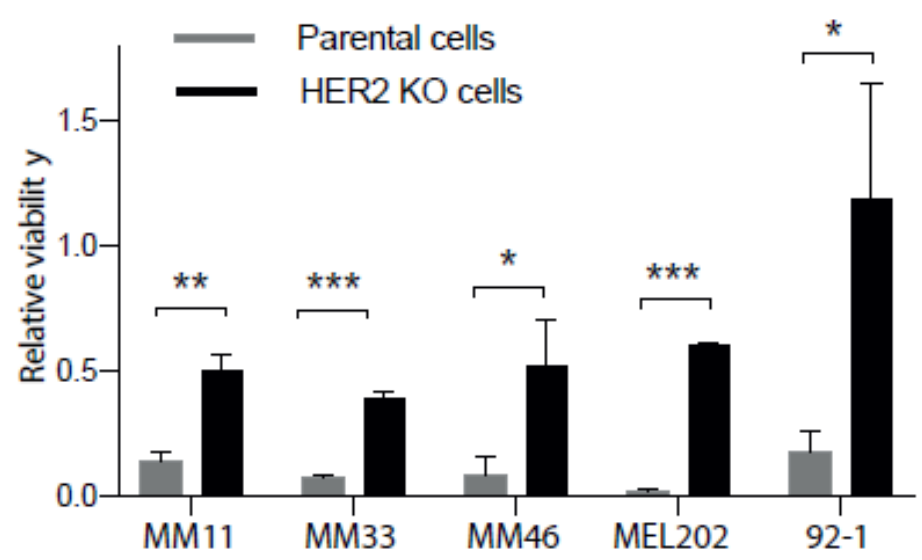

Gambar 5. Hasil perbandingan Penggunaan CAR T Cells Her2-Specific dengan terapi konvensional ${ }^{16}$

\section{KESIMPULAN}

Sebuah penelitian telah membuktikan keberhasilan CAR T Cells HER2- Specific sebagai upaya terapi UM yang mampu melakukan eliminasi sel tumor. Akan tetapi, efektivitas terapi CAR T Cells ini menimbulkan keadaan imunosupresi yang disebabkan oleh peningkatan ikatan PD1/PD-L1 pada sel tumor sehingga dibutuhkan suatu rekayasa genetika berupa CRISPR/Cas9 untuk mengganggu produksi PD-1. Hal ini ditunjukkan dengan efek yang signifikan terhadap penurunan ekspresi PD-1 oleh pdcd-1 sehingga efek imunosupresif yang ditimbulkan oleh terapi CAR T Cells dapat dihilangkan. Oleh karena itu, HER2Specific CAR T Cells termodifikasi CRISPR/Cas9 PD-1/PD-L1-Blocking dapat menjadi inovasi terapi gen pada penderita UM, yang nantinya diharapkan dapat meningkatkan angka harapan hidup pasien. Akan tetapi, hal ini masih diperlukan uji klinis lebih lanjut untuk membuktikan efektivitas CAR T Cells HER2-Specific termodifikasi CRISPR/Cas9 PD-1/PD- L1-Blocking dalam rangka terapi pasien UM.

\section{DAFTAR PUSTAKA}

1. Kranz B A, Dave N,Komatsubara K M, Marr B P, Carvajal R D. Uveal
Melanoma : Epidemiology, Etiology, and Treatment of Primary Disease.Clinical Ophthalmology. 2017. 11:279-289

2. Singh A D, Turell M E, Topham A K. Uveal Melanoma : trends in incidence, treatment, and survival. Ophtalmology.2011.118:1881-1885

3. Damato E M, Damato B E. Detection and time to treatment uveal melanoma in United Kingdom : an Evaluation of 2.384

patients.Ophtalmology.2012.119(8): 1582-1589

4. Damato B. Progress in management of patients with Uveal Melanoma: the 2012 ashton lecturer.eye(land). 2012.26(9).1157-1172

5. Komatsubara K M. Carvajal R D. Immunotherapy for the treatment uveal melanoma : current status and emerging therapies.Curr Oncol Rep.2017.19:45

6. Park S J. Oh C M. Kim B W. Woo S J. Coo H. Park K H. National wide incidence of ocular melanoma in south korea by using the National Cancer Registry Database ( 19992011).Invest Opthalmol Vis Sci. 2015.56(8):4719-4724

7. Shields C L. Kaliki S. Livesey M. Association of ocular and oculodermal melanocytosis with the rate of uveal melanoma metastasis : analysis of 7872 consecutive eye. JAMA Ophtalmol. 2013.131(8):993- 
1003

8. Turell M, Saunthararajah Y, Triozi P. Recent advances in prognostication for uveal melanoma. Ophtalmol Int. 2012:45-48

9. Kuk D, Shoushtari A N, Barker C A. Prognosis of mucosal, uveal, acral, con acral cutaneous and unknown primary melanoma from the first metastasis.Oncologist. 2016. 21(7) : 848-854

10. Blum E S, Yang J, Komatsubara K M, Carvajal R D. Clinical management of uveal and conjuctival melanoma. Oncology .2016. 30:29-48

11. Mariani P, Piperno-Neumann S, Servois V. Surgical management of liver matastases from uveal melanoma : 16 years experience at the institute curie. Eur J Surg Oncol. 2009.35: 1192-1197

12. Shields C L, Kaliki S, Furuta M, Fulco E, Alarcon C, Shields J A. American Joint committee on cancer classification of uveal melanoma ( anatomic stage ) predict prognosis in 7.731 patients :the 2013 zimmerman lecturer. 2013.122(6):1180-1186

13. Kaliki S, Shields C L. Uveal Melanoma: relatively rare but deadly cancer. Eye 2016.:1-17

14. Moriarty J P, Borah B J, Foote R L, Pulido J S,Shah N D. CostEffectiveness of Proton Beam Therapy for Intraocular Melanoma.Plos One.2015. 10(5):1-14

15. Morgan RA, Johnson LA, Davis JL, Zheng Z, Woolard KD. Recognition of Glioma Stem Cells by Genetically Modified T Cells Targeting EGFRvIII and Development of Adoptive Cell Therapy for Glioma. Hum Gene Ther. 2012. 23:1043-1053

16. Forsberg $\mathrm{E} M \mathrm{~V}$, Linberg $\mathrm{M} \mathrm{F}$, Jespersen $\mathrm{H}$, Alsen $\mathrm{S}$, Bagge $\mathrm{R} \mathrm{O}$, Donia M, Svane I M, Nilsson O, Ny L, Nilsson L M,Nilsson J A. HER2 CAR $T$ cells eradicate uveal melanoma and $\mathrm{T}$ cells therapy- resistant human melanoma in Interleukin-2( IL-2 ) transgenic NOD/SCID Il-2 receptor knockout mice.American Association for Cancer Research Journal.2019

17. Topalian S L. Safety, Activity, and immune correlates of Anti-PD-1 antibody in cancer.The New England Journal of Medicine.2012.366:24432554

18. $\mathrm{Su}$ S. CRISPR-Cas9 mediated efficient PD-1 distruption on human primary T-Cells from cancer patient. Sci rep. 2016

19. Chew W L. Immunity to CRISPRCas9 and Cas12 Therapeutic. Wiley interdiscip rev syst boil Med. 2018.10

20. Woodman S E. Metastatic Uveal Melanoma: Biology and Emerging Treatments.National Institure of health. 2012

21. Iqbal N, Iqbal N. Human Epidermal Growth Factor Receptor 2 (HER2) in Cancers: Overexpression and Therapeutic Implications. Molecular biology Int. 2014

22. Yu S, Li A, Liu Q, Li T. Chimeric antigen receptor $\mathrm{T}$ cells: a novel therapy for solid tumors. $J$ Hematol Oncol.2017.10(1):78

23. Magee M S, Snook A E. Challenges to chimeric antigen receptor (CAR)-T cell Therapy for cancer. Discov Med.2014.18(100):265-271

24. Scholler J, Brady T L, Binder-Scholl G, Hwang W T. Decade-long safety and function of retroviral-modified chimeric antigen receptor $\mathrm{T}$ cells.sci transl Med.2012.4(132)

25. Park JH, Geyer MB, Brentjens RJ. CD19-targeted CAR T-cell therapeutics for hematologic malignancies: interpreting clinical outcomes to date. Blood. 2016; 127(26):33120-20.

26. Wang Z, Wu Z, Liu Y, Han W. New development in CAR-T cell therapy. J Hematol Oncol. 2017; 10(1):53.

27. Curran KJ, Seinstra BA, Nikhamin Y, Yeh R, et al. Enhancing antitumor 
efficacy of chimeric antigen receptor $\mathrm{T}$ cells through constitutive CD40L expression. Mol Ther. 2015; 23(4):769-78.

28. Kerkar SP, Muranski P, Kaiser A, Boni A, et al. Tumor-specific CD8+ T cells expressing IL-12 eradicate established cancers in lymphodepleted hosts. Cancer Res. 2010; 70(17):67256734

29. Textor A, Listopad JJ, Perez C, et al. Efficacy of CAR T-cell therapy in large tumors relies upon stromal targeting by IFN $\gamma$. Cancer Res. 2014; 74(23):6796-805.

30. L. Porter, B.L. Levine, M. Kalos,A Bagg, C.H. June, Chimeric antigen receptor modified $\mathrm{T}$ cells in chronic lymphoid leukemia, N. Engl. J. Med. 2011. 365 (8). 725-733.

31. J.N. Kochenderfer, W.H. Wilson, J.E. Janik, M.E. Dudley, M. StetlerStevenson, S.A. Feldman, et al., Eradication of B-lineage cells and regression of lymphoma in a patient treated with autologous $\mathrm{T}$ cells genetically engineered to recognize CD19, Blood 11. 2010. 4099-4102.

32. Riegler LL, Jones GP, Lee DW. Current approaches in the grading and management of cytokine release syndrome after chimeric antigen receptor T-cell therapy. Therapeutics and Clinical Risk Management. 2019:15 323-335.

33. Topalian SL, Hodi FS, Brahmer JR, Gettinger SN, Smith DC, McDermott DF, Powderly JD, Carvajal RD, Sosman JA, Atkins MB, Leming PD, Spigel DR, Antonia SJ, et al. Safety, activity, and immune correlates of anti-PD-1 antibody in cancer. N Engl J Med. 2012; 366: 2443-54.

34. Chen DS, Irving BA, Hodi FS. Molecular pathways: next generation immunotherapy-inhibiting programmed death ligand 1 and programmed death-1. Clin Cancer Res. 2012; 18: 6580-7.

35. Patsoukis N, Brown J, Petkova V, Liu
F, Li L, Boussiotis VA. Selective effects of PD-1 on Akt and Ras pathways regulate molecular components of the cell cycle and inhibit T cell proliferation. Sci Signal. 2012; 5: ra46.

36. Sheppard K A, Fitz L J, Lee J M, Benander C, George J A, Wooters J, Qiu Y, Jussif J M, Carter L, Wood C R, Chaudhary D. PD-1 inhibits T- cell receptor induced phosphorylation of the ZAP70/CD3zeta signalosome and downstream signaling to PKCtheta. FEBS Lett. 2004; 574: 37-41

37. Parry RV, Chemnitz JM, Frauwirth KA, Lanfranco AR, Braunstein I, Kobayashi SV, Linsley PS, Thompson CB, Riley JL. CTLA-4 and PD-1 receptors inhibit $\mathrm{T}$-cell activation by distinct mechanisms. Mol Cell Biol. 2015; 25: 9543-53.

38. Hu J, Sun C, Bernatchez C, et al. T cell homing therapy for reducing regulatory $\mathrm{T}$ cells and preserving effector $\mathrm{T}$ cell function in large solid tumors. Clin Cancer Res. 2018.

39. Oestreich KJ, Yoon H, Ahmed R, Boss JM. NFATc1 regulates PD-1 expression upon $\mathrm{T}$ cell activation. $\mathrm{J}$ Immunol. 2008; 181: 4832-9.

40. Fuguo jiang and Jennifer A. Doudna. CRISPR/Cas9 Structures and Mechanisms. 2017. Annu. Rev. Biophys. 46:505-29.

41. Garneau JE, Dupuis M E, Villion M, Romero DA, Barrangou $\mathrm{R}$, et al. 2010. The CRISPR/Cas bacterial immune system cleaves bacteriophage and plasmid DNA. Nature 468(7320):67-71

42. Gasiunas G, Barrangou R, Horvath P, Siksnys V. 2012. Cas9-crRNA ribonucleoprotein complex mediates specific DNA cleavage for adaptive immunity in bacteria. PNAS 109(39):E2579-86

43. Jinek M, Chylinski K, Fonfara I, Hauer M, Doudna JA, Charpentier E. 2012. A programmable dualRNA- guided DNA 
endonuclease in adaptive bacterial immunity. Science 337(6096):81621

44. Chen H, Choi J, Bailey S. 2014. Cut site selection by the two nuclease domains of the Cas9 RNAguidedendonuclease. J. Biol. Chem. 289(19):13284-94

45. Zhang C, Peng Y, Hublitz P. Genetic abrogation of immune checkpoints in antigen-specific cytotoxic T- lymphocyte as a potential alternative to blockade immunotherapy. Scientific Repors. 2018. 8:5549. 